\title{
Impact of venture capital financing on small- and medium-sized enterprises' performance in Uganda
}

\begin{tabular}{|c|c|}
\hline \multicolumn{2}{|c|}{$\begin{array}{l}\text { Authors: } \\
\text { Ahmed I. Kato }{ }^{1} \text { (1) } \\
\text { Germinah E. Tsoka }{ }^{1} \text { (] }\end{array}$} \\
\hline \multicolumn{2}{|c|}{$\begin{array}{l}\text { Affiliations: } \\
\text { }{ }^{1} \text { Department of Applied } \\
\text { Management, College of } \\
\text { Economic Management } \\
\text { Sciences, University of South } \\
\text { Africa, Pretoria, South Africa }\end{array}$} \\
\hline \multicolumn{2}{|c|}{$\begin{array}{l}\text { Corresponding author: } \\
\text { Ahmed Kato, } \\
\text { ahmedkato2@gmail.com }\end{array}$} \\
\hline \multicolumn{2}{|c|}{$\begin{array}{l}\text { Dates: } \\
\text { Received: } 17 \text { Feb. } 2020 \\
\text { Accepted: } 04 \text { June } 2020 \\
\text { Published: } 23 \text { Sept. } 2020\end{array}$} \\
\hline \multicolumn{2}{|c|}{$\begin{array}{l}\text { How to cite this article: } \\
\text { Kato, A.I. \& Tsoka, G.E., 2020, } \\
\text { 'Impact of venture capital } \\
\text { financing on small- and } \\
\text { medium-sized enterprises' } \\
\text { performance in Uganda', } \\
\text { Southern African Journal of } \\
\text { Entrepreneurship and Small } \\
\text { Business Management } \\
\text { 12(1), a320. https://doi.org/ } \\
10.4102 / \text { sajesbm.v12i1.320 }\end{array}$} \\
\hline \multicolumn{2}{|c|}{$\begin{array}{l}\text { Copyright: } \\
\text { (c) 2020. The Authors. } \\
\text { Licensee: AOSIS. This wo } \\
\text { is licensed under the } \\
\text { Creative Commons } \\
\text { Attribution License. }\end{array}$} \\
\hline \multicolumn{2}{|l|}{ Read online: } \\
\hline 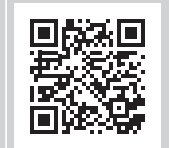 & $\begin{array}{l}\text { Scan this QR } \\
\text { code with your } \\
\text { smart phone or } \\
\text { mobile device } \\
\text { to read online. }\end{array}$ \\
\hline
\end{tabular}

Background: Small- and medium-sized enterprises (SMEs) in Africa and Uganda suffer from lack of finance for their survival and growth. This liquidity emergency motivated start-ups struggling to find alternative financing sources different from conventional bank lending. Venture capital financing evolved as viable financial mechanisms to revive SMEs' performance.

Aim: This article analysed the impact of venture capital financing on SMEs' performance in Uganda. This is the first empirical study that related and brought together the understanding of business entrepreneurs with those of venture capitalists.

Setting: The rate of start-up business failure in Africa remains high, triggering an enormous threat to policy-makers and international development partners. Besides, the literature is diminutive, intermittent and fragmented to document venture capital performance.

Methods: The study adopted a mixed-method and used survey questionnaires administered to $90 \mathrm{SMEs}$ and complemented with data from semi-structured interviews. We used multiple regression analysis and correlation coefficient for data analysis generated from the Statistical Package for the Social Sciences.

Results: Empirical evidence exhibited tremendous growth of venture-capital-backed companies in sales turnover, profitability and return on assets matched to the non-venturecapital-backed firms.

Conclusion: This article presented the first extensive empirical study confirming evidence of venture capital financing for the enhancement of SMEs' performance and development in Uganda regarding revenue growth, profitability and return on assets. This study recommended to policy-makers and the business fraternity to develop policy frameworks tailored to the enhancement of the venture capital landscape growth.

Keywords: venture capital; alternative financing; small and medium enterprises; performance of portfolio companies; Uganda.

\section{Introduction}

In the last two decades, venture capital (VC) financing has subjugated debates on global financial markets for the perceived momentous influence to inspire small- and medium-sized enterprises' (SMEs) performance. Empirical evidence, essentially from developed countries such as the United States of America, Canada, Europe and China, recognises VC as a viable financing model with the proficiency to escalate access to finance for SMEs' growth (Agyeman 2010; Gompers \& Learner 2004; Muriithi 2017; OECD 2018; Shanthi \& Schneider 2018). It is well documented that SMEs are the teamsters of economic growth, they attested to stimulate the national Gross Domestic Product (GDP) development and they are the principal employment sector in both industrialised and emerging economies (Beck \& Cull 2014; Mason 2009; Shanthi \& Schneider 2018). In Uganda, the SME sector fundamentally accounts for 2.5 million jobs, provides $90 \%$ of the private sector jobs, produces $80 \%$ of the manufactured output and endorses 70\% of the national GDP (Muriithi 2017; Uganda Investment Authority 2016; Uganda Ministry of Trade, Industry and Cooperatives [UMTIC] 2015).

Despite the economic importance of the SME sector to Uganda's national economy and similar emerging economies, the rate of start-up business failure remains a general concern to policy-makers and international development partners. The contemporary literature suggests that the mortality rate of SMEs among African countries is alarming, with five out of seven (5/7) 
new businesses failing in their first year (World Bank 2016). In Uganda, $33.3 \%$ of new business formations do not survive beyond 1 year of their start-up (Mbabazi 2012; Muriithi 2017). Similarly, the results of Yeboah and Koffie (2016) exhibited that $75 \%$ of start-up firms in South Africa close business in less than 3 years after their formation, one of the highest SMEs mortality rates in the world. The failure rate of SMEs is attributable to lack of finance, the topmost stumbling block for start-up survival and development, as equated to the rest of the world (World Bank 2010). Although SMEs struggle to search for external debt capital to bridge the financing gap, financial intermediaries consider them as high-risk investment ventures and are, therefore, reluctant to provide them with bank loans or financial credit (Fatoki 2014).

In this context, VC financing emerged as an alternative source to conventional funding to fill the equity gap and benefit the missing middle. The new finance mechanisms uphold the legitimacy in augmenting the growth of SMEs. Fund managers provide patient capital to start-up firms and congruently provide technical skills and add value to the portfolio companies, expecting good returns on investments (Gompers, Kaplan \& Mukharylamov 2015; Colombo \& Murtinu 2017). Furthermore, venture capitalists typically secure minority seats on the Board of Directors (BOD) from the VC-backed firms to boost their financial performance to achieve high returns on equity (ROE) shares (Arundale 2018; Hain, Johan \& Wang 2016; OECD 2018; Ryan \& Hankook 2013; Shanthi \& Schneider 2018).

Given this, for the VC market to flourish in Uganda and developing economies at large, it is incumbent upon both the public and private sector structures to increase VC investment into the early stage entrepreneur ventures with growth potential. This approach was confirmed in the developed economies for extenuating the financing gap impeding SME development. This article resonates from the empirical evidence from the industrialised markets that have demonstrated success in spurring SME growth through VC financing, such as the United States of America, Europe and China. This article presents recent knowledge to the policymakers and researchers to assist in the design of appropriate policies for VC industrial growth in Uganda. Because of conferring a concrete evidence base, the article supports the government's efforts in their engagements to foster SMEs' access to finance and inspires a philosophy of policy assessment. This article empirically analyses the impact of VC financing on SMEs' performance in Uganda.

\section{Literature review of venture capital performance}

\section{Theoretical perspective}

Venture capital is a high-risk equity capital consisting of seed, start-up and expansion financing in start-up firms already demonstrating business potential but not listed on public securities markets or underprivileged to access traditional funding sources (Gompers \& Lerner 1999; OECD
2018). Venture capital financing is a momentous financial innovative asset in the 21st century, raising the attention of academics and practitioners. Several scholars have recognised it as a precursor for SMEs' growth, global technological development and employment generation (Arundale 2018; Muriithi 2017; Ning, Wang \& Yu 2015). Resonating on the agency theory, this study offers a theoretical model reflecting on the hypothetical and practical implications of the theory regarding the VC ecosystem.

Venture capital provides patient capital to young firms financially incapacitated and continues to oversee their operations as principals. The interactions of venture capitalists with the funded companies set in motion noticeable principalagent conflict, emanating from information asymmetries and fear of the business owner or managers to lose control over their investments (Amit, Brander \& Zott 1998). The VC firms (principals) enter VC contracts with the business entrepreneurs (agents) to promote early or middle-level firms in exchange for equity shares and to protect the interests of both parties to the contract. Similarly, venture capitalists secure minority seats on the BOD to maintain a sound business and add value to portfolio companies to recuperate worthy ROE shares (Cumming \& Johan 2009; Lerner 1995; Kaplan \& Lerner 2016).

The practical implications of the agency theory postulate interrelated conflict of interest, which could emerge at the execution of the contract when venture capitalists choose to exit from the company through initial public offerings (IPOs) or a trade sale. That said, the VC contract is vital to guard against eventual disputes between the portfolio managers and venture capitalists accordingly, resonating with the agency theory (Hellmann \& Puri 2002). It, therefore, is extremely valuable for the business entrepreneurs to appreciate the unique nature of venture financing before signing any VC contracts to avoid any conflict that might arise in the execution of the contract.

Altogether, entrepreneurs repeatedly face the problem of lack of access to finance, consequently compelled to accept patient capital from fund managers specialising in financing high-risk firms. This certainly demands SMEs to agree with venture capitalists to access the financing needed for their growth and expansion, enforcing VC contracts.

\section{Overview of global venture capital performance}

In the last two decades, $\mathrm{VC}$ has dominated debates on the global financial markets for its perceived momentous influence in inspiring the performance of SMEs. A colossal body of empirical literature from developed countries recognises VC as a suitable financing model, with proficiency to ease the barrier of lack of access to finance for SMEs growth (Gompers \& Learner 2004; Muriithi 2017; OECD 2018; Shanthi \& Schneider 2018). It is well documented that most global companies such as YouTube, Yahoo, Apple, Microsoft and Compaq have their roots from $\mathrm{VC}$ financing. Most authors paint an intriguing picture of VC financing. Given the high-risk nature of the early stage 
firms, some VC-funded companies do not blossom to their expectations, but there is inadequate evidence that exposes failed VC-backed companies. Shedding more light on the recent successful firms in the past decade stemming from VC financing is necessary to enrich the extant works with recent knowledge.

From the global VC performance perspective, VC investment hit its highest at US\$171 billion in 2019, with the United States of America alone raising US $\$ 88.3 \mathrm{~b}$, approximately $50 \%$ of the global total VC investment, upholding its first position as world VC leader for decades. China progressed to the second position with US\$52.6 b of the global VC market (Pitchbook 2019; WeeTracker 2019). Notably, VC investment to Europe is also silently increasing (EVCA 2015), and Africa is mentioned as the next favoured destination for VC investment. Even though some countries have a much smaller VC portfolio, they are worth mentioning for their remarkable growth 2019, for instance, Canada, the United Kingdom, India, Brazil, Israel, Malaysia and Africa on the frontline presenting Nigeria, Kenya and South Africa, the champions in the continent. Other countries such as Ghana, Egypt, Uganda and Tunisia are trailing (KPMG \& EAVCA 2019; WeeTracker 2018; Deloitte 2015).

Conscious of VC financing's significant influence, voluminous emerging economies in Africa, including Uganda, are increasingly stepping up to participate in the VC industry. It is undeniable that VC is viewed as a real-world answer to rejuvenate the growth of SMEs to avert the emergent youth unemployment, poverty eradication and economic development. Given this, WeeTracker (2019) reported a gigantic growth in the VC investment from US\$725.6 million to $1.34 \mathrm{~b}$ in 2019 , a monumental year in the history of Africa. Remarkably, US\$1.09 b (approximately 81.5\%) was raised from Nigeria and Kenya, pushing South Africa to the third position compared to 2018 when the latter was the leader in the VC industry. This clear testimony of VC growth in Africa has seen new entrants such as Uganda, Tunisia, Ghana and Egypt as the next favoured investor destination.

Accordingly, VC development has delivered a novel ground for academic research to explore its influence on the performance of early-stage entrepreneurial ventures. Nevertheless, it should not be overlooked why VC investment, particularly in Africa, is concentrated in Nigeria, Kenya and South Africa, while the rest of the countries, including Uganda, are struggling (VC4Africa 2015). These are key issues demanding further exploration into the VC industry.

\section{Empirical evidence of venture capital financing}

This section critically documents empirical data stressing VC performance specifically in developed economies and a handful of studies from emerging economies. Several scholars from technologically advanced economies have long established that VC finance is a reality in augmenting the growth of SMEs. Unlike the debt-funding model, VC provides patient capital to start-up firms showing growth potential and without collaterals to offer in exchange for lucrative equity shares that attract ROE (Arundale 2018; Bertoni \& Tykovova 2015; Gompers \& Learner 2004; Mason, Botelho \& Harrison 2013; OECD 2018).

Puri and Zarutskie (2011) disclosed that VC-backed firms outperformed the non-VC-backed firms across every level of investment both before and after receiving VC. On the same line, Paglia and Harjoto (2014) launched a crosssectional study in the United States of America from 1995 to 2009 to examine the effects of PE/VC on the growth of sales and employment for SMEs. The results demonstrated a slow growth of the PE/VC baked firms, and the benefits of PE were higher than VC financing. Similarly, Chemmanur, Krishnan and Nandy (2011) studied a panel of data analysis matching VC-backed companies with non-VC-backed companies. The results affirmed increasing total productivity from sales revenue after VC financing. However, the profits were lower compared to the significant market expansion of the VC-backed firms, implying that even though funded companies increased their market shares, they did not translate into profitability growth. There is a lack of literature consensus among the scholars that vehemently explain how VC financing affects the portfolio companies.

Likewise, Jain and Kini (1995) matched 136 sampled US-listed companies receiving VC funding before IPO with a matched sample of non-VC-funded IPO companies in the same comparable size. The authors identified growth in sales from the year before and after the IPO and the subsequent 3 years. Venture capital-backed companies significantly surpassed the non-VC-funded matched group. Nevertheless, this study was done in the United States of America blessed with sophisticated technological development. Moreover, the world model for VC financing might not deliver the same results, given that the VC landscape in Uganda is small and underdeveloped. Consequently, augmenting it with new data sets adds more value to the literature in the public domain.

Although previous authors presented compelling results to support VC financing, Hirukawa and Ueda (2008) found no significant relationship between using VC and an industry's growth. Venture capital-backed companies did not generate more sales and employment compared to non-VC-backed companies. They exposed that only VC-backed companies performing $R \& D$ realise higher sales turnover than non-VC-backed companies. These inconsistencies in empirical studies stimulate supporting research in the academic domain.

Furthermore, Hain, Johan and Wang (2016) explored VC financing and its subsequent effect on SMEs' growth in the United States of America. They used panel data from the major commercial databases for the first quarter of 2011 and updated data from the second quarter of 2015. Their empirical 
evidence suggests that VC-backed companies outperform public markets. Despite the appealing results, the commercial databases on which the authors relied could provide conflicting results attributable to data protection and privacy of private equity firms. Further research conducted in an emerging economy, such as Uganda, is desirable, where little or no empirical research is done to provide empirical data to benchmark future research.

Carvalho, Netto and Sampaio (2013) investigated the influence of $\mathrm{PE} / \mathrm{VC}$ on SMEs' performance in Brazil. The results confirmed that $\mathrm{PE} / \mathrm{VC}$-backed firms registered higher profitability and sales growth compared to non-PE/VCbacked firms in the first 3 years after the IPO. Several empirical studies have explored VC financing, focusing largely on sales turnover and profitability for measuring their growth. However, little is documented about ROA and $\mathrm{ROE}$, the core interest of the fund managers. This article includes new proxies such as ROE and ROA used in the measurement of SMEs' performance. Kaplan and Lerner (2009) disclosed that although only $0.2 \%$ received VC financing, surprisingly, $50 \%$ of the entrepreneurial IPOs in recent years were VC-backed companies. Nevertheless, notwithstanding the growing attention given $\mathrm{VC}$ financing, several studies concentrate on VC after IPOs. This study explores the impact of VC financing on early stage firms in a developing country.

Groh, Liechtenstein and Lieser (2010) alluded that nonfinancial factors, such as the tax regimes, negatively affect VC capital. In contrast, Hain et al. (2016) found the conclusion of the previous author not substantive because the design of a favourable policy framework eases access to VC financing promoting growth. Kamunge, Njeru and Tirimba (2014) shed more light on the government regulatory frameworks, expounding that they can either encourage or subdue the growth of the SME sector. Effective government regulations, such as content law policy, tax regimes, wages framework, licensing, investment opportunities, technological support and infrastructure, if well-managed, pave the way to SMEs' success.

Memba, Gakure and Karanja (2012) analysed the impact of $\mathrm{VC}$ on the performance of SMEs from the major cities in Kenya, involving 100 respondents. They measured the before and after approach using both financial and nonfinancial variables. The results exposed a significant positive relationship between VC financing and SME growth. Venture capital-backed companies demonstrated growth in sales revenue, profitability and the number of employees. Their study involved only entrepreneurs and managers for primary data collection. This study covers a broad continuum of key players in the VC market, such as business entrepreneurs and managers, fund managers, government agencies and SME associations, offering a deeper insight into the operation of the VC industry.

Kwame (2017) conducted a study from Ghana's capital Accra using data collected from 40 SMEs to examine the impact of VC financing on SMEs' growth. The outcomes confirmed an expansion of the market share, increased asset growth and profitability of VC-backed firms. Biney (2018) studied the impact of VC financing on SMEs' growth and development in Ghana. The results indicated that VC-backed firms outperformed non-VC-backed firms by a mild increase of $1.5 \%$ in sales revenue, profitability, and a $3.7 \%$ growth in the number of employees.

Boadu (2014), in his study, Venture capital financing: An opportunity for SMEs in Ghana, found a positive impact of VC financing on SMEs' growth. They manifested this in the remarkable growth and expansion of VC-backed companies that recorded $16.7 \%$ overall growth. Jobs increased by $33.3 \%$, consistent with the economic indicators of the business sector. Suweiba and Haibo (2019) examined 100 VC-backed companies in Ghana to determine if they registered growth post-VC investment. The findings confirmed a positive and significant relationship between the growth of VC-backed firms and VC instruments. These studies show varied results, yet they were conducted in the same country, Ghana. Therefore, it is challenging to conclude that the findings from Uganda might be the same as Ghana's because of the countries' economic differences and regulatory policies.

Mboto, Amenawo and Udoka (2018) used non-probability sampling by the Yamane formula, and a sample of 40 SMEs from the cross-river state in Nigeria was selected. They found that firms receiving VC funding increased their opportunity to access other sources of funding, and there were positive sales growth and an increase in net assets. However, the method used for non-probability sampling could lead to biased results because it creates an equal opportunity for each SME in the region to be selected. Such drawbacks in the available literature necessitate more research in the field of VC finance to provide a clear understanding of its impact on SME performance, specifically in Uganda.

\section{Venture capital performance in Uganda}

In a larger context of East Africa, the VC market is progressively developing. Nevertheless, most of the VC deals are concentrated in Nairobi, Kenya, enhanced by the manifestation of Silicon Savannah and the East African Private Equity \& Venture Capital Association (EAVCA) headquartered in Nairobi. Current literature suggests that the growth of the VC industry in developed and transitional economies is attributable to the private equity investors' efforts to add value to the portfolio companies, with a greater focus on SME growth (Gompers et al. 2015; Rusu \& Toderascu 2016). However, Uganda's VC industry is new and underdeveloped equated to Kenya, the VC market leader in the East African block. Relatively few empirical studies exist to underpin the influence of VC financing on SMEs' growth. Even though the VC market is small, it has attracted the attention of the international VC firms to exploit the untapped SME sector. The recent study of AVCA (2019) points out that Uganda, Egypt, Ghana and Tunisia are the next destinations 
for private equity financing in Africa. The fund managers are mostly headquartered in Kenya, and a few foreign international limited partners have revamped the VC industry in Uganda. These include Ascent Capital, Pearl Capital Partners, XSML Partners, Savannah Capital Partners, Norfund, Iungo Capital Partners and XSML Partners. Notably, the cost of running VC funding in Africa is high compared with that of other markets.

The VC market in Uganda represents an infinitesimal fraction of the overall quantity of fund investment in the East African block. In an effort to assist SMEs gain more knowledge, widen their networks with the VC firms and enhance their success for raising patient capital needed to propel their business growth, Uganda Investment Authority organised the first ever alterative annual finance conference. The annual conference brings together all the stakeholders in the VC market with the intent to accelerate the growth of SMEs through PE/VC alternative funding. It is important to highlight that access to patient capital by the small firms remains a national concern.

Fund managers and business angels available on the market target large and reputable enterprises that can absorb tickets above US\$5 m (Shanthi \& Shariff 2014). In isolation, VC tickets in Uganda range from US\$250 000 to US\$1 000000 (Ernst and Young 2016). This explains why Uganda's VC market is grappling. This is because government programmes to fill the financing gap have realised minor success.

In conclusion, VC financing stimulates the growth of start-up firms and is a sustainable solution to their equity gap. Access to VC finance remains challenging, particularly for fast-growing firms, with antagonistic repercussions on economic growth (OECD 2018). There is little evidence documenting the effect of VC financing on the growth of SMEs. The existing literature offers mixed results. This article, therefore, provides a new data set illuminating the impact of VC financing on the growth of SMEs.

\section{Research methodology}

The article adopted an exploratory research method to obtain a deeper insight into the VC industry, given the limited data available to underpin VC performance in Uganda. Earlier scholars, such as Numally and Bernstein (1994) illuminated that exploratory research is suitable for investigating a problem having limited knowledge of previous scholarships or in the absence of any literature on which to benchmark. We applied a mixed-method technique for primary data collection, incorporating both quantitative and qualitative research methods. The mixed-method has strengths of engaging the interpretivism and positivism paradigms that complement each other either proportionately or disproportionately (Creswell 2003; Saunders, Lewis \& Thornhill 2012). Previous researchers have also used the mixed-method research approach (Kwame 2017; Memba et al. 2012; Mabhungu 2017) and commended it for yielding reliable and valid data sets.

\section{Sample and data collection}

The study used a 5-point Likert scale survey questionnaire administered to 90 key respondents in the VC market, complemented with face-to-face interviews held with the portfolio company managers, VCs, government agencies and SMEs associations. The quantitative research method is more dominant because firms' performance is measured by financial indicators. The researchers opted for survey questionnaires because it is ostensibly easier for managers to provide financial data to safeguard confidential information (Song et al. 2005). Besides, it has the benefit of saving time and the hustle of recording the questions and answers, managing many topics and analysis of data (Collis \& Hussey 2009; Saunders, Lewis \& Thornhill 2009). The researchers found the survey questionnaires comfortable for the respondents, as it permits them to complete the questions at their convenience, given that the target respondents comprised a customarily busy class. The respondents provided their scores ranging from strongly disagree (1) to strongly agree (5). The average score for agreeing was 3.5 and above.

Stratified random sampling was used to select 90 respondents from a total population of 300 SMEs from the manufacturing and agribusiness sectors. The study targeted the districts with the highest concentration of SMEs situated in the Kampala, Wakiso, Mukono and Jinja districts. The researchers categorised the SMEs into VC-backed and non-VC-backed firms. Small- and medium-sized enterprises from the manufacturing sector were chosen because they contributed $21.62 \%$ to the total national revenue collections, then to the fast-moving consumer goods sector (URA 2018), while agribusiness makes up $67 \%$ of Uganda's economy. The primary source of data was the UIA database and Uganda Small Scale Industries Association (USSIA). Small- and medium-sized enterprises included in the study were those classified by UIA as the top-performing SMEs in 2018 and 2019. Because there was no segregated database for VCbacked firms, the researchers also used the profiles of active VC firms in Uganda. These were extracted from the UIA catalogue for the annual PE/VC conference organised for 2015 and 2016 and the EAVCA online published membership database. The VC firms included Pearl Capital Partner, Norfund, Sigma Capital, Mango Fund, Syndicate Africa, Ascent Capital, Fincon Africa, XSML Capital, Catalyst Principal Partners, Actis Capital, Fanisi VC, Iungo Capital and Kibo Capital Partner. The researchers engaged these categories because they compose the highest decisionmaking body of SMEs inclined with a wealth of knowledge and custody of the data required for the study. The researchers interacted with all the key players in the VC industry and compiled their understanding of $\mathrm{VC}$ performance, best practices and challenges.

\section{Data analysis}

The first step was to organise the survey questionnaires to ensure that they were completed and suitable for data analysis. Questionnaires with many gaps for data analysis 
were eliminated. The researchers analysed quantitative data using descriptive statistics, inferences, financial ratio analysis and excel. The multiple regression model statistically measured the relationship between VC financing and SMEs' performance. Face-to-face interviews were recorded and transcribed, and data were transferred to Atlas-ti for analysis. Face-to-face interviews allowed the researchers to interact with the respondents, request clarity of any discrepancies in statistical data and received access to audited accounts that added value to the research.

In measuring the SMEs' performance, the researchers considered sales turnover, ROA and profitability to determine the extent to which the independent variable influences the dependent variables. The multiple regression model is illustrated as:

$Y=\alpha+\beta \mathrm{X} 1+\beta \mathrm{X} 2+\beta \mathrm{X} 3+\epsilon$

where:

- $Y=\mathrm{VC}$

- $\quad \beta X 1=$ annual sales

- $\beta X 2=$ profitability

- $\beta X 3=\mathrm{ROA}$

- $\alpha=$ intercept

- $\epsilon=$ residual (error)

- VC-backed and non-VC-backed are binary variables allocated 1 if SMEs received VC financing and 0 if they did not receive $\mathrm{VC}$ financing.

\section{Measurement of the study variables}

Business performance is a mirror habitually used by business entrepreneurs and researchers to assess the survival and growth of firms. Scholars in business finance define performance as a parameter used by enterprises to measure the capacity of total assets to generate revenue. The researchers hypothesise that VC financing enhances the growth of SMEs, regarding an increase in sales turnover, profitability growth and ROA as the performance variables to be evaluated. Financial ratios were also used to analyse business financial performance, such as sales turnover, profitability and ROA. They facilitate a realistic way to compare companies of different industries and assist to match business enterprises across different sectors, be it big or small, to recognise their strengths and weaknesses. The researchers extracted data from the survey questionnaires and financial reports and analysed it to compare both VC-backed and non-VC-backed firms' performance. Scholars of corporate finance acknowledge financial ratio analysis as the most essential financial evidence used by firm management and other stakeholders to assess the financial stability and growth potential of a firm.

\section{Validity and reliability of data}

Validity is the extent to which the research findings reflect the phenomena under investigation (Collis \& Hussey 2009). We can evaluate the validity of research under face validity, construct validity, content validity or discriminant validity (Collis \& Hussey 2009; Sekaran 2005). The researchers conducted a pilot study to evaluate the reliability and content validity of the research instruments used in the study. The questionnaire was evaluated for reliability using Cronbach's alpha coefficient with a 95\% significant confidence level and $5 \%$ allowable margin of error (Table 1). This approach was also in the previous studies of VC (Biney 2018).

The researchers processed the results using SPSS version 25. Cronbach's alpha coefficient is more suitable because it can measure reliability and content validity, as recommended by Numally and Bernstein (1994). The results showed a $98.4 \%$ confidence level of the survey questionnaire and a margin error of $1.6 \%$, which was much lower than the estimated $5 \%$.

\section{Empirical analysis and discussion of results}

To measure the impact of VC financing on SMEs' growth, the researchers extracted data from 68 hand-collected survey questionnaires out of the 90 distributed, thus accounting for a $76 \%$ response rate. Previous authors confirm that a response rate of $50 \%$ is sufficient for numerical data analysis and 70\% is good (Mugenda 2011).

Furthermore, 16 face-to-face interview sessions were conducted out of 30 targeted interviews. These targeted business owners and managers, VCs and government agencies had vast knowledge and approval authority for access to financial data required for the study. The researchers extracted the data from audited accounts, management financial reports, narrative reports and open-ended questionnaires. The annual revenue, ROA growth and profitability for 3 years (2016-2018) were also computed using ratio analysis. The financial ratios can minimise the subjectivity associated with other data collection methods and help to supplement data collected by using the Likert scale survey questionnaires (Dess \& Robinson 1984).

Several tests from SPSS were conducted, such as descriptive statistics, multiple linear regression, Pearson's correlation coefficient and analysis of variance (ANOVA), to determine any relationship between $\mathrm{VC}$ financing and SMEs' performance. The researchers explained any ambiguities of numerical data from the face-to-face interview discourse (Figure 1).

Figure 1 shows that VC-backed firms had a higher revenue growth rate across all years from 2016 to 2018. The researchers used 2015 as the base year denoted as zero. In 2016, VC-backed firms recorded a growth rate of $15 \%$ as compared to $7 \%$ for non-VC-backed firms. In 2017, the growth rate increased to $22 \%$, whereas non-VC-backed firms registered $14 \%$, and in the third year, the VC-backed firms indicated $18 \%$ versus $10 \%$ for the non-VC-backed firms.

TABLE 1: Testing results for Cronbach's alpha reliability statistics.

\begin{tabular}{lcc}
\hline Cronbach's alpha & $\begin{array}{c}\text { Cronbach's alpha based on } \\
\text { standardised items }\end{array}$ & Number of items \\
\hline 0.508 & 0.984 & 68 \\
\hline
\end{tabular}




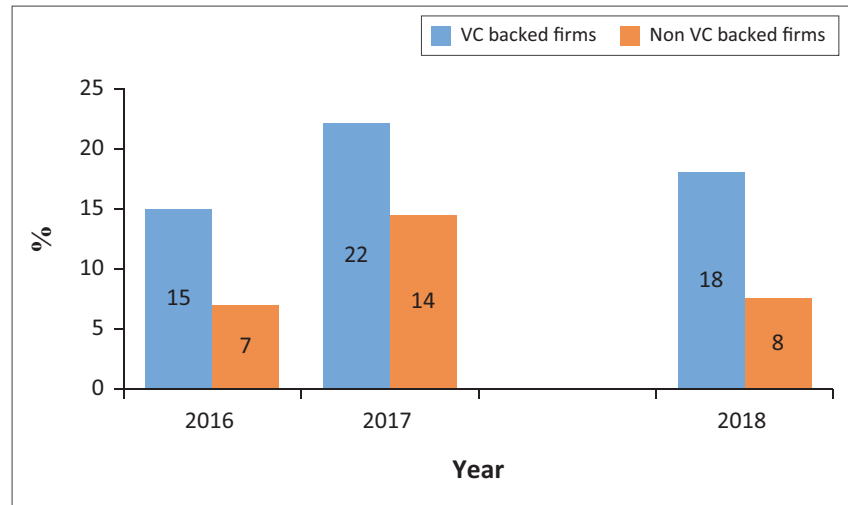

VC, venture capital.

FIGURE 1: Sales revenue growth for the VC-backed and non-VC-backed firms from 2016 to 2018.

TABLE 2: The level of significance between venture capital financing (independent variable) and its influence of the sales revenue growth of venture capital-backed firms (dependent variables).

\begin{tabular}{llcc}
\hline $\begin{array}{l}\text { Pearson's correlation } \\
\text { coefficient }\end{array}$ & Variable & Venture capital & $\begin{array}{c}\text { Sales revenue } \\
\text { growth }\end{array}$ \\
\hline Venture capital & Pearson's correlation & 1 & $0.435^{* *}$ \\
& Sig. (2-tailed) & - & 0.000 \\
& $N$ & 68 & 68 \\
Sales revenue growth & Pearson's correlation & $0.435^{* *}$ & 1 \\
& Sig. (2-tailed) & 0.000 & - \\
& $N$ & 68 & 68 \\
\hline
\end{tabular}

Note: When $p<0.05$ results indicate a significant correlation between venture capital finance and sales revenue.

VC, venture capital; Sig., significance.

*, Correlation is significant at the 0.05 level (2-tailed) of $p<0.05$; **, correlation is significant at the 0.01 level (2-tailed).

The analysis of the revenue trends exposed that VC-backed firms outperformed non-VC-backed firms for all the 3 years. Notably, in 2018, there was a decline of $4 \%$ and $6 \%$ in revenue growth for both VC-funded and non-VC-funded companies, respectively. While the variation in revenue growth appears insignificant regarding revenue figures, there is an enormous difference. The maximum revenue turnover for VC-backed SMEs was UGX 18 billion against UGX 4 billion for the non-VC-backed firms for 2016-2018. Therefore, the growth rate method was employed because it can offset hiccups of only comparing maximum and minimum sales, given the reason that it considers the total average annual revenue for all firms under review. This proves that sales revenue increased significantly. The researchers conclude that VC financing leads to increased sales revenue growth, which was consistent with previous studies (Adongo 2012; Kwame 2017; Memba et al. 2012).

The researchers also performed Pearson's correlation coefficient tests to determine the relationship between VC financing and sales turnover.

Table 2 displays the correlation coefficient results for sales revenue at 0.000 . The correlation is significant when $p<0.01$ and $p<0.05$. The results are below $p<0.01$, demonstrating a significantly strong relationship between VC financing and the sales revenue growth for VCbacked firms. These results are similar to the findings of

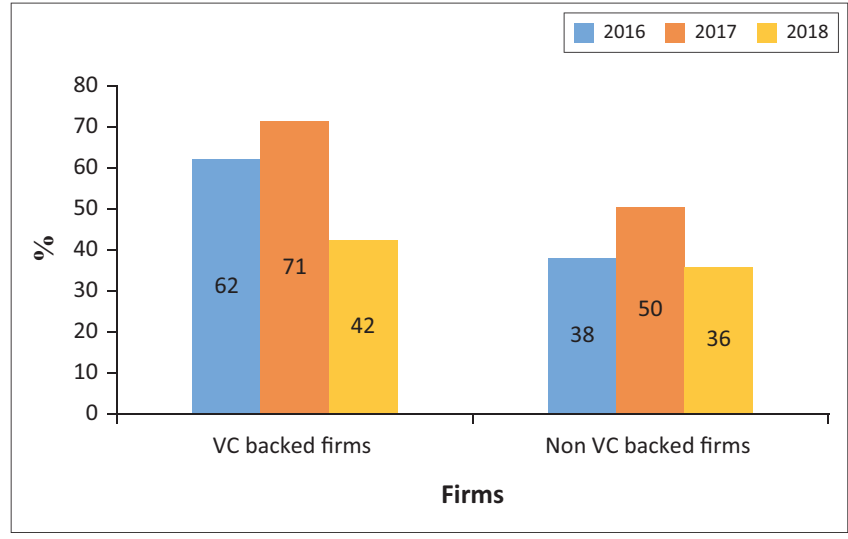

VC, venture capital.

FIGURE 2: Asset growth for VC-backed and non-VC-backed firms for 3 years, from 2016 to 2018 .

Memba et al. (2012) and Biney (2018). The researchers, therefore, conclude that the changes in the sales revenue growth for the VC-backed companies are explained by VC financing, implying that after receiving VC, sales revenue went up.

In the approach to measuring the growth in assets, the researchers computed ROA growth for both the VC-backed and non-VC-backed firms to adequately compare whether VC financing influences asset growth.

Figure 2 shows the computed results for ROA growth. The year 2015 was the base year denoted as X0, 2016 as X1, 2017 as X2 and 2018 as X3. For 2016, the results show an increase in ROA by $62 \%$ for the VC-funded firms as compared to $38 \%$ for the non-VC-funded firms. In the second year of VC financing, ROA increased to $71 \%$ compared to $50 \%$ for the non-VC-backed firms. However, in 2018, both VC-backed and non-VC-backed firms had a decline in ROA growth. The results indicate that VC-backed firms generated more sales revenue as alluded by other scholars. The rise in ROA growth in 2016 and 2017 was attributed to the expansion of firms to meet the increased demand for their goods and services. Although holding a top asset base might not explain a firm's performance, the critical issue is the capacity of the company's assets to generate sales revenue to meet ROE for the shareholders.

A Pearson's correlation coefficient test was also conducted to examine if there is any relationship between VC financing and Returns on Assets (ROA).

Table 3 shows the correlation coefficient $r$ for ROA at 0.05 . The correlation coefficient is significant when the $p$-values are $p<0.01$ and $p<0.05$. The results show a $p<0.05$. These results confirm there is a strong positive relationship between VC financing and changes in ROA. The higher the ROA, the more effective is the use of assets to the advantage of shareholders. These results imply that $\mathrm{VC}$ financing is positively correlated to ROA, implying that the asset for the 
TABLE 3: The Pearson's correlation test for venture capital financing and ROA.

\begin{tabular}{llcc}
\hline Financing & Variable & $\begin{array}{c}\text { Venture } \\
\text { capital }\end{array}$ & ROA \\
\hline Venture capital & Pearson correlation & 1 & $0.336^{* *}$ \\
ROA & Pearson correlation & $0.336^{* *}$ & 1 \\
& Sig. (2-tailed) & 0.005 & - \\
& $N$ & 68 & 68 \\
\hline
\end{tabular}

VC, venture capital; ROA, return on assets.

*, Correlation is significant at the 0.05 level (2-tailed) of $p<0.05$; **, correlation is significant at the 0.01 level (2-tailed).

TABLE 4: SPSS descriptive statistics measurement of small- and medium-sized enterprises' growth using profitability growth.

\begin{tabular}{lccccc}
\hline Variable & $\boldsymbol{N}$ & Minimum & Maximum & Mean & SD \\
\hline Profitability growth & 68 & 2.00 & 5.00 & 3.7 & 0.68279 \\
VCs direct involvement & 68 & 1.00 & 5.00 & 3.8 & 0.87836 \\
increase profitability & & & & & \\
Market share and expansion & 68 & 2.00 & 5.00 & 3.7 & 0.74549 \\
Valid $N$ (listwise) & 68 & - & - & - & - \\
\hline
\end{tabular}

$\mathrm{VC}$, venture capital; SD, standard deviation.

VC-backed firms produced higher sales following receipt of VC financing. Descriptive statistics measured profitability growth.

Likert scale measure: 1 - Strongly disagree and 5 - Strongly agree, and accepted a mean score of 3.5 (agree).

Table 4 shows a mean score of 3.7 and 0.68279 above the acceptable score for agreeing of 3.5. The findings indicate that $68 \%$ of the respondents confirmed the growth of their companies' profits being attributable to VC financing. Besides, the results also indicated a mean score of 3.8 and a standard deviation (SD) of 0.87836 for the $\mathrm{VCs}^{\prime}$ direct involvement in SME management, while the market share recorded a mean score of 3.7 and an SD of 0.74549 . These results show a profitability growth after $\mathrm{VC}$ financing, $\mathrm{VCs}^{\prime}$ direct involvement in SMEs' management contributed to the increase in the profitability growth, and VC-funded companies improved their market share and expansion. The market share and expansion move along with increased productivity to meet the outrageous demand in the market for goods and services. The researchers, therefore, conclude that VC financing contributes to the growth of profitability, market share and expansion and, finally, that the VCs involvement in the portfolio companies is critical to improving their performance. The researchers conducted multiple regression tests for the statistical relationship between VC financing and profitability growth (Table 5).

The results in Table 5 show profitability growth at 0.000 , a significant positive relationship between VC financing and profitability. This, therefore, shows that a change in VC financing positively affects profitability growth.

Furthermore, the least-squares is $R^{2}=0.342$ and adjusted $R^{2}=0.289$, showing that the variations in the dependent variable (profitability growth) of $34.2 \%$ are illuminated with VC financing into the portfolio companies. The researchers, therefore, can conclude that VC financing contributed to profitability growth by $34.2 \%$. Some scholars criticise the
TABLE 5: Tests between venture capital financing and profitability growth effects.

\begin{tabular}{lccccc}
\hline Source & $\begin{array}{c}\text { Type III sum } \\
\text { of squares }\end{array}$ & $d f$ & Mean square & $\boldsymbol{F}$ & Significance \\
\hline Mean square & $10.695 \dagger$ & 5 & 2.139 & 6.456 & 0.000 \\
Residual & 20.540 & 63 & 0.326 & - & 0.000 \\
\hline Total & $\mathbf{3 1 . 2 3 5}$ & $\mathbf{6 8}$ & - & - & - \\
\hline
\end{tabular}

Note: Dependent variable: Profitability growth.

$d f$, degrees of freedom.

$\dagger, R^{2}=0.342$ (adjusted $R^{2}=0.289$ )

profitability method in measuring business performance because they restrict it to past performance and unrealistic approach of treating depreciation and amortisation as part of the annual expenses; however, they do not involve any direct cash flows. These findings were consistent with the study (Biney 2018; Carvalho et al. 2013; Kwame 2017; Paglia \& Harjoto 2014).

\section{Ethical consideration}

The study was approved by the research ethics committee under the information removed to ensure blind peer review before commencing with the fieldwork. Besides, the researcher received authorisation from the UIA and Uganda Small Scale Industries Association before commencing the research for access to the SMEs database.

\section{Summary and conclusion}

This article presented one of the first extensive empirical studies confirming evidence of the impact of VC financing on SMEs' performance in Uganda. The findings disclose exciting empirical results. Venture capital financing affects the performance of VC-backed firms. The researchers observed that sales revenue increased fourfold for VC-backed firms, higher than non-VC-backed firms. Venture capital-backed firms disclosed a maximum sales revenue of UGX 18 billion (US $\$ 4.90 \mathrm{~m}$ ) as compared to UGX 4.6 billion (US $\$ 1.25 \mathrm{~m}$ ) for non-VC-backed firms.

Furthermore, the profitability for VC-backed firms increased by $28.9 \%$, while the ROA increased by $71 \%$ because of the increased demand for local exports in the East African community. Previous studies have used the before and after the matching method, implying that firms are assessed at different time intervals. This study investigated the definite performance of VC-backed and non-VC-backed firms from 2016 to 2018, in consideration of the same timeframe and investment environment. This suggests that the microeconomic factors influence both variables, thus providing a reasonable evaluation, which helped to produce reliable results.

This study contributes to new knowledge on the underexplored studies completed about the impact of VC financing on SMEs' performance in developed economies. The study offers the first empirical study conducted that relates and brings together the understandings of business entrepreneurs, government agencies and VCs. The researchers also unveil a comprehensive account underlining the success of VC financing from both 
developed and emerging markets to assist policy-makers and specialists in designing appropriate policies that inspire the growth of the VC ecosystem. Previous studies lacked a literature consensus on VC financing's influences on the performance of VC-backed firms and interesting imminent research to offer novel understanding in the public domain. This study further discloses existing gaps in the current literature and offers recommendations for the future research agenda.

Previous studies in the emerging markets have focused on the early stage firms, neglecting the IPOs or trade sales that the VCs strive to achieve at their exit stage from the funded companies. Out of the sample of 68 respondents, there were no IPOs or trade sale companies. This concludes the limited accessible literature for studies exploring the impact of VC on IPOs or trade sale. Supplementary results from the face-to-face interviews revealed that business entrepreneurs have less interest to list on the stock exchange market because of the distress of loss of control of their industries. The researchers suggest extra research in this sector to assess how VC influences IPOs or trade sales in the emerging markets.

Furthermore, the researchers discovered that most of the VCfunded companies were in their third year following receipt of VC financing. Impact measurement at this level can be associated with survivorship bias. At this stage, they might invest more expenditure in $R \& D$, acquisition of assets and product development to promote the company reputation, which could affect the profitability growth of the firm. Previous scholars have disclosed that the profitability growth for the portfolio companies diminishes in the later stage of funding. Therefore, the need for future exploration is necessary to determine if profitability growth is lower in the later stage of VC investment, as explained by other scholars.

Several studies used only portfolio managers as key respondents to measure VC performance on the growth of VC-backed firms. This approach neglects the critical insight of the key players in the VC market. This study brings together a comprehensive understanding of all key players in the VC industry, such as portfolio managers, government agencies, fund managers and SMEs' associations. The researchers discovered that only $50 \%$ of the VC-backed companies were operating as expected, $30 \%$ were struggling and $20 \%$ failed. This shows that not all VC-backed companies make it to the top, as most literature displays, but that VC firms only present successful ventures. Previous studies present only successful VC-backed companies; however, they revealed that $20 \%$ of the funded companies failed and $30 \%$ were trailing.

Uganda's VC industry is minor, underdeveloped and fragmented. The researchers encountered some difficulty in collecting the required information for the study. The business entrepreneurs exhibited little knowledge about the importance of empirical research to the SME sector; hence, some declined to provide reports supporting their financial performance. The researchers also noted that whereas the VC market is picking up, the available SMEs in Uganda have little capability to absorb the VC deals of US\$5 m, hindering the growth of the SME sector. These findings were similar to (Rusu \& Toderascu 2016), who conducted studies in the emerging markets in Europe. The researchers suggest that researchers explore why Uganda's VC industry has attracted little attention from the business entrepreneurs amidst the entry of foreign VC firms in the financing of highrisk entrepreneurial ventures. More precisely, numerous authors have proved that VC financing is a sustainable financing model propelling SMEs' growth.

\section{Acknowledgements}

Our special thanks go to Department of Applied Management, University of South Africa for the invaluable support that contributed to the success of this manuscript.

\section{Competing interests}

The authors have declared that no competing interests exist.

\section{Authors' contributions}

All authors contributed equally to this work.

\section{Funding information}

This research did not receive any funding from the public or not-for-profit sectors.

\section{Data availability statement}

Although this is an original article, data sharing is not applicable for this article for purposes of data protection and privacy from third-party persons.

\section{Disclaimer}

The views and opinions expressed in this article are those of the authors and do not necessarily reflect the official policy or position of any affiliated agency or the authors.

\section{References}

Adongo, J., 2012, 'The impact of the legal environment on venture capital and private equity in Africa empirical evidence', Journal of Public Economics 90(8-9), 1699-1723.

African Private Equity and Venture Capital Association (AVCA), 2019, African PE \& VC Performance Benchmark Q4 2018 Report 2019, viewed from https://www.avcaafrica.org/research-publications/data-reports/.

Agyeman, S.K., 2010, 'Challenges facing venture capitalists in developing countries: An empirical study about venture capital industry in Ghana', Master's thesis, Umeå School of Business, Umeå.

Amit, R., Brander, J. \& Zott, C., 1998, 'Why do venture capital firm exist? Theory and Canadian evidence', Journal of Business Venturing 13(6), 441-466. https://doi. org/10.1016/S0883-9026(97)00061-X

Arundale, K., 2018, 'Exploring the difference in performance between UK/European venture capital funds and US venture capital funds', Ph.D thesis 'Submitted in fulfilment of the requirements of the Degree of Doctor of Philosophy, Adam Smith Business School, College of Social Sciences University of Glasgow, viewed from http://theses.gla.ac.uk/30827/1/2018ArundalePhd.pdf. 
Beck, T. \& Cull, R., 2014, Small and medium-sized enterprise finance in Africa. African Growth Initiative (working paper 16), Brookings, Washington, DC

Bertoni, F. \& Tykhova, T., 2015, 'Does governmental venture capital spur invention and innovation? Evidence from young European biotech companies', Research Policy 44(4), 925-935. https://doi.org/10.1016/j.respol.2015.02.002

Bertoni, F., Colombo, M. \& Quas, A., 2015, 'The patterns of venture capital investment in Europe', Small Business Economics 45(3), 543-560.

Biney, C., 2018, 'The impact of venture capital financing on SMEs growth and development in Ghana', Business and Economics Journal 2018, 9(3). https://doi. org/10.4172/2151-6219.1000370

Boadu, F., 2014, 'Venture capital financing: An opportunity for small and medium scale enterprises in Ghana', Journal of 'Entrepreneurship and Business Innovation 2014, 1(1). https://doi.org/10.5296/jebi.v1i1.5187

Carvalho, A., Netto, H. \& Sampaio, J., 2013, Conducted as research on private equity and venture capital in Brazil analysing its recent evolution, viewed 15 April 2018 from http://papers.ssrn.com/sol3/papers.cfm?abstract_id=1996729.

Chemmanur, T., Krishnan, K. \& Nandy, D., 2011, 'How does venture capital financing improve efficiency in private firms? A look beneath the surface' Review of Financial Studies viewed 15 April 2018, from http://ssrn.com/abstract=1025322.

Collis, J. \& Hussey, R., 2009, Business research: A practical guide for undergraduate and postgraduate students, 3rd edn., Palgrave Macmillan, Basingstoke.

Colombo, M. \& Murtinu, S., 2017, 'Venture capital investments in Europe and Portfolio firms' economic 1136 performance: Independent versus corporate investors', Journal of Economics Management \& Strategy 26(1), 35-66. https://doi. org/10.1111/jems.12170

Creswell, J.W., 2003, Research design: Qualitative, quantitative, and mixed methods approaches, 2nd edn., Sage, Thousand Oaks, CA.

Cumming, D.J. \& Johan, S.A., 2009, Venture capital and private equity contracting: An international perspective, Elsevier Science Academic Press, Amsterdam.

Deloitte, 2015, Africa private equity confidence survey: 2015, Deloitte Financing avenues through commercial lenders, Johannesburg.

Dess, G. \& Robinson, R.B., 1984, 'Measuring organisational performance in the absence of objective measures: The case of the privately held firm and conglomerate business unit', Strategic Management Journal 5(3), 265-273. https://doi.org/10.1002/smj.4250050306

Dzeletovic, M., Milosevic, M. \& Cicic, S., 2017, 'Venture capital: Generator of growth of SME investment activities', Industrija 45(3), 7-22. https://doi.org/10.5937/ industrija45-11210

Ernst and Young, 2016, Back to reality, EY global venture capital trends 2015, viewed 30 July 2019, from www.ey.com/Publication/vwLUAssets/ey-global-venturecapital-trends2015/EY-globalventure-capital-trends-2015.pdf.

EVCA, 2015, European private equity venture capital association-annual report for 2015 and the report on private equity impact on economic growth in Europe.

Fatoki, O., 2014, 'The financing options for new small and medium enterprises in South Africa', Mediterranean Journal of Social Sciences 5, 748-755. https://doi. org/10.5901/mjss.2014.V5n20p748

Gompers, P. \& Lerner, J., 2004, The venture capital cycle, MIT Press, Cambridge, MA.

Gompers, P., Kaplan, S. \& Mukharylamov, V., 2015, What do private equity firms say they do? Harvard Working Paper Series, 15-081, Harvard Business School, Boston.

Gompers, P.A. \& Lerner, J., 1999, 'Conflict of interest in the issuance of public securities: Evidence from venture capital', Journal of Law \& Economics 42(1), $1-28$.

Groh, A., Von Liechtenstein, H. \& Lieser, K., 2010, 'The European venture capital and private equity country attractiveness indices', Journal of Corporate Finance 16(2), 205-224. https://doi.org/10.1016/j.jcorpfin.2009.09.003

Hain, D., Johan, S. \& Wang, D., 2016, 'Determinants of cross-border venture capital investments in emerging and developed economies: The effects of relational and institutional trust', Journal of Business Ethics 138(4), 743-764. https://doi. org/10.1007/s10551-015-2772-4

Hellmann, T. \& Puri, M., 2002, 'Venture capital and the professionalization of start-up firms: Empirical evidence', The Journal of Finance 57(1), 169-197.

Hirukawa, M. \& Ueda, M., 2008, Venture capital and innovation: Which is first? Working Paper, viewed 17 June 2018, from http://ssrn.com/abstract=1242698

Jain, B. \& Kini, O., 1995, 'Venture capitalist participation and the post-issue operation performance of IPO firms', Journal of Managerial and Decision Economics 16(6), 593-606. https://doi.org/10.1002/mde.4090160603

Kamunge, M., Njeru, A. \& Tirimba, O., 2014, 'Factors affecting the performance of small and macro enterprises in Limuru town market of Kiambu County", International Journal of Scientific and Research Publications 4(12), 1-20.

Kaplan, S. \& Lerner, J., 2016, Venture capital data: Opportunities and challenges, Working Paper 17-012, University of Chicago Press for National Bureau of Economic Research, Chicago, IL.

KPMG \& EAVCA, 2019, Private Equity Sector Survey of East Africa for the period 2017 to 2018, June, p. 44, EAVCA, Nairobi, viewed 10 September 2019, from https:// assets.kpmg/content/dam/kpmg/ke/pdf/deal/PE\%20Survey\%20Booklet\%20 2019.pdf.

Kwame, B., 2017, 'Assessing the impact of venture capital financing on growth of SMEs', Texila International Journal of Management 3(2), 2017. https://doi. org/10.21522/TIJMG.2015.03.02.Art004

Lerner, J., 1995, 'Venture capitalists and the oversight of private firms', The Journal of Finance 50(1), 301-318.
Mabhungu, S., 2017, 'A performance measurement framework to enhance the success and survival of retail micro, small and medium enterprises', Doctor of Philosophy in the Subject Management Accounting at the University of South Africa.

Mason C., Botelho, T. \& Harrison, R., 2013, The transformation of the business angel market: Evidence from Scotland, Report by the University of Glasgow business market: Evidence from Scotland, Report by the University of Glasgow business https://www.research.ed.ac.uk/portal/files/12536283/Harrison_Transformations https://ww

Mason, C.M., 2009, 'Public policy support for the informal venture capital market in Europe: A critical review', International Small Business Journal 27(5), 536-556. Europe: A critical review', International Sma
https://doi.org/10.1177/0266242609338754

Mason, C.M. \& Harrison, R., 2015, 'Business angel investment activity in the financial crisis: UK evidence and policy implications', Environment and Planning $C$ Government and Policy 33(1), 43-60. https://doi.org/10.1068/c12324b

Mbabazi, A., 2012, The speech read at the Uganda Top 100 mid-size companies-Gala Dinner at Serena Hotel, unpublished, Kampala on 23 November 2012.

Mboto, H., Amenawo, I. \& Udoka, C., 2018, 'Venture capital financing and the growth of small and medium-scale enterprises in Cross River State, Nigeria', Global Journal of Management and Business Research: C Finance 18(3), 2018.

Memba, F., Gakure, W. \& Karanja, K., 2012, 'Venture capital (VC): Its impact on growth of small and medium enterprises in Kenya', International Journal of Business and Social Science 3(6), 32-38.

Ministry of Finance Planning \& Economic Development, 2018, Accountability Sector Annual Report 2018/2019, viewed 31 July 2019, from https://www.finance.go.ug/ publication/accountability-sector-annual-report-fy-2018-19.

Motavaseli, M., Shojaei, S., Bitaab, A., Chitsazan, H. \& Ghanbar, M., 2018, 'Institutional barriers to financing technology-based small firms through venture capital mechanism: A study to explore the incentives for investment in Iran', Internationa Journal of Economics and Financial Issues 10(3), 409-427. https://doi. org/10.1108/JEEE-01-2018-0001

Mugenda, A.G., 2011, Social science research methods: Theory and practice, Nairobi, ARTS Press.

Muriithi, S., 2017, 'African small medium enterprises, contributions, challenges, and solutions', European Journal of Research and Reflection in Management Sciences 5(1), 2017

Ning, Y., Wang, W. \& Yu, B., 2015, 'The driving forces of venture capital investments', Small Business Economics 44(2), 315-344. https://doi.org/10.1007/s11187-0149591-3

Numally, J. \& Bernstein, I., 1994, Psychometric theory, 3rd edn., McGraw-Hill, New York, NY.

Organisation of Economic Cooperation Development (OECD), 2018, Enhancing SME access to diversified financing instruments, Discussion Paper 22-23 February 2018, Mexico City.

Paglia, J. \& Harjoto, M., 2014, 'The effects of private equity and venture capital on sales and employment growth in small and medium-sized businesses', Journal of Banking \& Finance 47(2014), 177-197. https://doi.org/10.1016/j.jbankfin. 2014.06.023

Pitchbook, 2019, Global PE \& VC Fund. Performance Report as Q2 2018, viewed from https://files.pitchbook.com/website/files/pdf/PitchBook_Global_PE_VC_Fund Performance_Report_as_of_2Q_2018.pdf.

Puri, M. \& Zarutskie, R., 2012, 'The life cycle dynamics of venture capital and nonventure capital financed firms', Journal of Finance 67(6), 2247-2293. https://doi. org/10.1111/j.1540-6261.2012.01786.x

Rusu, V. \& Toderascu, C., 2016, 'Venture capital financing in emerging economies', CES Working Papers VIII(1), 148-162, viewed from https://www.researchgate.net/ publication/303283032.

Ryan, K. \& Hankook, K., 2013, Venture capital as a catalyst for high growth: Working Paper 2013-01. Economic Research and Policy Analysis Branch Industry Canada viewed 21 July 2019, from http://www.ic.gc.ca/eic/site/eas-aes.nsf/eng/h ra02218.html.

Sanders, M., Lewis, P. \& Thornhill, A., 2009, Research methods for business students, 5th edn., Pearson Education, Harlow.

Saunders, M., Lewis, P. \& Thornhill, A., 2012, Research methods for business students, Pearson Education, Harlow.

Sekaran, U., 2005, Research methods for business: A skill-building approach, 4th edn Wiley \& Johns, New York.

Shanthi, D. \& Schneider, S., 2018, Ghana private equity and venture capital ecosystem study, Policy Research Working Paper 8617, viewed viewed 13 March 2018, from https://elibrary.worldbank.org/doi/abs/10.1596/1813-9450-8617.

Shanthi, D. \& Shariff, M., 2014, Private equity and venture capital in SMEs in developing countries. The role for technical assistance, Policy Research Working Paper 6827 The World Bank Capital Markets Practice Non-Bank Financial Institutions Unit, World Bank Group, Washington, DC.

Song, M., Droge, C., Hanvanich, S. \& Calantone, R., 2005, 'Marketing and technology resource complementarity: An analysis of their interaction effect in two environmental contexts', Strategic Management Journal 26(3), 259-276. https:// doi.org/10.1002/smj.450

Suweiba, S. \& Haibo, C., 2019, 'Exploring the effect of venture capital instruments and control mechanisms on growth of venture capital fund: Empirical evidence from Ghana', Open Journal of Business and Management 7(1), 180-193, viewed 21 March 2020, from http://www.scirp.org/journal/ojbm. 
Uganda Investment Authority, 2016 Second Private Equity, and Venture Capital Conference 2016, Kampla'Serena 24th-25th June 2015, viewed 15 April 2018 , Conference 2016, Kampla'Serena 24th-25th June 2015, viewed 15 April 2018,
from https://www.ugandainvest.go.ug/wp-content/uploads/2016/04/PEVCfrom https:/

Uganda Ministry of Trade, Industry, and Cooperatives, 2015, Uganda Micro, Small and Medium Enterprise (MSMEs) policy, Final Draft 2015, viewed 25 March 2018 https://www.ugandainvest.go.ug/wp-content/uploads/2016/02/Final-MSMEPolicy-July-2015.pdf

Uganda Revenue Authority, 2018, Annual Revenue Performance Report FY 207/2018, viewed 31July 2018, from https://www.ura.go.ug/Resources/webuploads/ GNRART/Annual\%20Revenue\%20Report_2017_18.pdf.

VC4Africa, 2015, Venture finance in Africa: 'The progress of early-stage high potential growth companies', VC4Africa, viewed 15 April 2018, https://vc4a.com/ blog/2014/12/17/vc4africa-2015-report-venture-finance-in-africa/.
WeeTracker, 2018, African venture Capital Report 2018, viewed 18 August 2019, from https://weetracker.com/2019/01/04/what-a-year-the-state-of-venture-capitalin-Africa-2018.

WeeTracker, 2019, Decoding venture capital investment in Africa, viewed 15 April 2020, from https://weetracker.com/venture-capital-africa-2019-report/

World Bank Report, 2016, Doing business 2016: Measuring regulatory quality and efficiency, World Bank Group, Washington, DC.

World Bank, 2010, World Bank enterprise survey 2010, World Bank Washington, DC.

Yeboah, A. \& Koffie, F., 2016, 'Does the legal form of small and medium enterprises determine their access to capital?', International Journal of Management, Accounting, and Economics 3, 520-533, viewed 09 July 2018, from http://www. ijmae.com/. 